\title{
Influence of glutamine on morphological and functional changes of liver in the presence of extrahepatic biliary obstruction in rats ${ }^{1}$
}

\author{
Influência da glutamina em alterações funcionais e morfológicas do fígado na vigência de \\ obstrução biliar extra-hepática em ratos
}

\author{
Manoel Camelo de Paiva Neto ${ }^{\mathrm{I}}$, Rosimara Eva Ferreira Almeida', Marcelo Magalhães Xavier ${ }^{1 \mathrm{I}}$, Gustavo Henrique Soares Takano ${ }^{\mathrm{II}}$, \\ Orlando de Castro e Silva JrIII, Carlos Augusto Teixeira da Cruz ${ }^{\text {IV }}$, João Batista de Sousa ${ }^{\text {IV }}$ \\ ${ }^{I}$ Graduate student, Faculty of Medicine, UnB, Brasilia-DF, Brazil. \\ ${ }^{\text {II } M a s t e r, ~ P a t h o l o g y ~ A n a t o m y ~ S e r v i c e, ~ H U B, ~ B r a s i l i a-D F, ~ B r a z i l . ~}$ \\ III PhD, Full Professor, Head of Digestive Surgery Division, Department of Surgery and Anatomy, Ribeirão Preto School of Medicine (FMRP-USP), \\ São Paulo, Brazil. \\ Iv Associate Professor of Surgical Clinics, Faculty of Medicine, UnB, Brasilia-DF, Brazil.
}

\begin{abstract}
Purpose: To study the influence of glutamine on functional and morphological changes of liver in the extrahepatic biliary obstruction through an experimental model in rats. Methods: Seventy Wistar rats were divided into four groups: control (group C) fictitious operation, (group FO), submitted to laparotomy with handling of bile ducts, but without hepatic duct ligation, (group EBO) submitted to laparotomy and hepatic duct ligation, one of them submitted to supplementation with glutamine $2 \%$ (group G). The control group consisted of 6 animals. The animals from groups FO, EBO and G were divided into three groups consisting of 6 animals each, being sacrificed at 7, 14 and 21 days after operation, respectively. Blood samples were collected for biochemical analysis and a fragment of liver tissue was collected from the middle lobe for histological analysis. Results: Both for biochemical analysis (BT, aspartate and alanine aminotransferase AST, ALT and alkaline phosphatase FAL) and for histopathological changes (fibrosis, portal inflammation, parenchymal inflammation, hepatocytic changes and duct proliferation), no statistical difference between groups submitted to extrahepatic biliary obstruction (EBO) with and without treatment with glutamine (G) was observed. Conclusion: Glutamine supplementation did not alter the prognosis of liver enzymes and histopathological changes in animals submitted to extrahepatic biliary obstruction.
\end{abstract}

Key words: Cholestasis, Extrahepatic. Glutamine. Liver. Rats.

\section{RESUMO}

Objetivo: Estudar a influência da glutamina em alterações funcionais e morfológicas do fígado na obstrução biliar extra-hepática por meio de um modelo experimental desenvolvido em ratos. Métodos: Setenta ratos Wistar distribuídos em quatro grupos: controle (grupo C); operação fictícia (grupo OF), submetido à laparotomia com manuseio das vias biliares, mas sem ligadura do ducto hepático; (grupo $\mathrm{OBE}$ ), submetido à laparotomia exploradora e ligadura do ducto hepático, sendo um deles submetido à suplementação com glutamina a $2 \%$ (grupo G). O grupo controle era composto por seis animais. Os animais dos grupos OF, OBE e G foram divididos em três grupos compostos por seis animais cada e que foram sacrificados no $7^{\circ}, 14^{\circ}$ e $21^{\circ}$ dias após a operação, respectivamente. Foi colhido sangue para análise bioquímica e um fragmento de tecido hepático do lobo médio para estudo histológico. Resultados: Tanto em relação à analise bioquímica (BT, aspartate and alanine aminotransferase AST, ALT e FAL) quanto em relação às alterações histopatológicas (fibrose, inflamação portal, inflamação parenquimatosa, alterações hepatocíticas e proliferação de ducto), não houve diferença estatística entre os grupos submetido a obstrução biliar extra-hepática sem (OBE) e com tratamento com glutamina (G). Conclusão: A suplementação com glutamina não alterou o prognóstico em relação às enzimas hepáticas e alterações histopatológicas nos animais submetidos à obstrução biliar extra-hepática.

Descritores: Colestase Extra-Hepática. Glutamina. Fígado. Ratos.

${ }^{1}$ Research performed at Experimental Laboratory of Surgery, School of Medicine, University of Brasília (UnB) and Pathology Anatomy Service, Brasilia University Hospital (HUB), Brazil.

\section{Introduction}

Extrahepatic biliary obstruction is associated with high postoperative morbidity and mortality rates ${ }^{1}$. Whatever the origin, it is associated with morphological and functional injury of the liver ${ }^{2-4}$, and a lower immune resistance, factors that contribute significantly to various postoperative complications such as sepsis, bleeding disorders and kidney failure ${ }^{1}$. The following are 
among the main changes: increased serum levels of direct bilirubin, resulting from canalicular retro-diffusion; increased levels of alkaline phosphatase (ALP) and gamma-glutamyltranspeptidase (gamma-GT), while the aspartate and alanine aminotransferase levels (AST and ALT) can be normal or high, all due to the hepatocyte membrane injury secondary to the biliary stasis ${ }^{2,3,5}$. Morphologically, dilation with duct proliferation and periportal hepatitis and septal fibrosis apoptosis bridges and necrosis can be both observed, which may lead to cirrhosis ${ }^{2}$. The loss of the hepatic structure also leads to progressive change of the function of this organ, which can be observed by the elevation of indirect bilirubin, due to its non conjugation, and by the change in the synthesis of serum proteins such as albumin and coagulation factors ${ }^{2}$. Besides the bile stasis, other possible injury mechanisms include the production of free radicals ${ }^{2,4}$.

Several experiments have shown the role of glutamine as protective agent against these free radicals ${ }^{6,7}$. Supplementation with glutamine and alanine-glutamine dipeptide was effective in increasing the hepatic synthesis of antioxidant enzymes, protecting the tissue from the action of free radicals in rats submitted to total parenteral nutrition ${ }^{6}$. In a hepatic ischemia-reperfusion injury model, treatment with alanine-glutamine dipeptide seemed to preserve the antioxidant capacity, to protect the structure and mitochondrial function and to decrease the production of free radicals ${ }^{8}$. Another study showed protection against liver injury induced by hemorrhagic shock in rats by the best use of cellular energy, decreased apoptosis and improved survival rate ${ }^{9}$. The antioxidant function in other systems has also been confirmed in an experiment where the administration of glutamine improved vascular reactivity by decreasing the production of cytokines and free radicals involved in a septic shock model in rats ${ }^{7,10}$. Other roles played by this substance include the autophagic proteolysis regulation, synthesis of glycogen and fatty acids, insulin signaling, protection against apoptosis, especially in the canalicular excretion of bile acids ${ }^{11}$, besides presenting a trophic potential on hepatocytes. The metabolism of glutamine in the liver is involved in the systemic detoxification by ammonia and blood $\mathrm{pH}$ regulation ${ }^{11}$.

The amino acid glutamine appears to have anabolic properties for various organic systems. Its supplementation has resulted in beneficial clinical outcomes ${ }^{12}$. Many authors have postulated that glutamine can prevent or reduce the total bilirubin values. However, several experimental studies have reported conflicting results, which were attributed to the animal models used $^{13}$. A study in rats submitted to extrahepatic biliary obstruction tested enteral glutamine supplementation and showed BT and gamma GT levels significantly lower and TGP levels significantly higher in the group receiving glutamine supplementation ${ }^{14}$.

However, there are few studies on the effect of glutamine on extrahepatic cholestasis models. A study on double ligation, followed by resection between points, decreased the apoptosis of hepatocytes and bile duct proliferation in rats after 3 days of ligation, not showing the same effect 7 days after operation in groups of 5 animals ${ }^{5}$. Another study, with double ligation followed by resection between ligations resulted in decreased duct proliferation in relation to the group without glutamine supplementation ${ }^{15}$.

Several studies in literature have been evaluating the effects of enteral and parenteral glutamine supplementation. Studies in critically ill patients and surgical patients showed that the parenteral administration was more effective in increasing plasma concentrations in relation to oral administration ${ }^{16,17}$. Another study in mice showed that when L-alanyl-L-glutamine was enterally administrated, there was a more significant increase for the synthesis of L-citrulline and L-arginine in relation to the parenteral administration ${ }^{18}$. Since results of studies on enteral or parenteral glutamine supplementation proved to be conflicting due to possible differences in metabolism depending on the type of administration, it is necessary to conduct a research involving the clinical benefit of enteral glutamine.

The project goal was to evaluate the influence of enteral glutamine on enzymatic and histological hepatic alterations of rats submitted to extrahepatic biliary obstruction, taking into account its protective role against damages caused by the production of free radical from cholestasis.

\section{Methods}

This study was developed at the Laboratory of Experimental Surgery, School Medicine, of University of Brasilia and Pathology Anatomy Service - Brasilia University Hospital.

The study was carried out within the guidelines of the Brazilian College of Animal Experiments (COBEA) and was submitted and approved by the Ethics Committee in Animal Research of the Biological Sciences Institute, University of Brasilia.

All surgical procedures were performed with Xylazine 2\% $(10 \mathrm{mg} / \mathrm{kg})$ and ketamine $10 \%(100 \mathrm{mg} / \mathrm{kg})$ intramuscularly applied. Then, abdominal trichotomy, cleansing with iodine alcohol and laparotomy were performed.

The animals from group of Fictitious Operation (FO) were submitted to handling of bile ducts.

The animals from groups Extrahepatic Biliary Obstruction (EBO) and $\mathrm{G}$ were submitted to ligature of the hepatic duct.

\section{Animals and experimental design}

Seventy male Wistar rats weighing between 250 and 350 $\mathrm{g}$ and 90 days of age were divided into four groups:

1. Group C (Control): 6 animals for control;

2. Group FO (fictitious operation): 18 rats submitted to laparotomy and handling of the bile duct without bile duct ligation (fictitious operation);

3. Group EBO (Extrahepatic Biliary Obstruction): 18 animals submitted to EBO induction through the folding of the hepatic duct; Ref

4. Group $\mathrm{G}$ (treated with glutamine): 6 animals submitted to laparotomy with bile duct ligation and treated with glutamine $2 \%$ (aqueous solution).

The animals from groups FO, EBO and $\mathrm{G}$ were divided into three groups consisting of 6 animals each, submitted to euthanasia at 7, 14 and 21 days after operation, respectively.

During the study period, the animals were kept in cages for 5 animals. The animals were kept at room temperature and were submitted to a light / dark cycle of 12 hours each. All animals received rat chow and water ad libitum and, in the case of animals from the treated group (group $\mathrm{G}$ ), the water contained $2 \%$ of glutamine.

Blood samples and liver tissue fragments were collected immediately before the euthanasia of each rat. Measurements of bilirubin, aminotransferase and alkaline phosphatase were made, as well as histopathological analysis of liver fragments. 


\section{Histopathological study}

Liver tissue samples were fixed in formaldehyde solution $10 \%$, embedded in paraffin and stained with hematoxylin-eosin. Histopathological study was performed by a pathologist who was unaware of the conditions and analyzed the presence of fibrosis or portal inflammation and parenchymal inflammation. All parameters were given a score from 0 to 4 , following this pattern: " 0 " no change " 1 " mild changes, " 2 " moderate changes " 3 " marked changes and "4" very substantial changes.

Moreover, nuclear changes, edema, reticular degeneration and necrosis of hepatocytes were evaluated using the following scores: " 0 " no change "1" nuclear changes, "2" hydropic degeneration, " 3 " reticular degeneration and apoptosis and " 4 " confluent necrosis, thrombi, biliary lakes and cholestasis receiving the following score: "0" zero, "1" intrahepatic cholestasis, "2" intra canalicular cholestasis, " 3 " thrombosis and "4" lakes, and duct proliferation receiving the following score: "0" zero, "1" mild, " 2 " moderate, " 3 " marked and " 4 " very severe.

\section{Statistical analysis}

The results were analyzed through the Kruskal-Wallis test followed by Dunn's method for comparison between groups with significance of $5 \%(\mathrm{p}<0.05)$ for all parameters.

\section{Results}

All animals from EBO and G groups evolved with signs and symptoms of cholestasis.

Both for biochemical analysis (BT, TGO, TGP and FAL) and histopathological changes (fibrosis, portal inflammation, parenchymal inflammation, hepatocystic changes and duct proliferation), there was no significant difference between the EBO groups treated with glutamine for 7 (G7), 14 (G14) and 21 days (G21) compared to groups submitted to EBO for 7 (EBO 7), 14 (EBO 14) and 21 days (EBO 21). (Table 1 to 6) (Figure 1 to 4).

TABLE 1 - Median, minimum and maximum values of fibrosis score in the groups Control (C), Fictitious Operation (FO), Extrahepatic Biliary Obstruction (EBO) and Treated with Glutamin $(\mathrm{G})$ for 7, 14 and 21 days

\begin{tabular}{lccc}
\hline \multicolumn{1}{r}{ Groups } & Median & Min & Max \\
\hline C & 0 & 0 & 0 \\
FO7 & 0 & 0 & 0 \\
EBO7 & 1 & 0 & 1 \\
G7 & 0,5 & 0 & 2 \\
FO14 & 0 & 0 & 0 \\
EBO14 & 1,5 & 1 & 2 \\
G14 & 2,5 & 1 & 3 \\
FO21 & 0 & 0 & 1 \\
EBO21 & 2 & 1 & 3 \\
G21 & 1 & 0 & 3 \\
\hline
\end{tabular}

Kruskal-Wallis test; $\mathrm{p}<0.0001$
TABLE 2 - Median, minimum and maximum values of portal inflammation score in the groups Control (C), Fictitious Operation (FO), Extrahepatic Biliary Obstruction (EBO) and Treated with Glutamin (G) for 7, 14 and 21 days

\begin{tabular}{lccc}
\hline \multicolumn{1}{r}{ Groups } & Median & Min & Max \\
\hline C & 0 & 0 & 0 \\
FO7 & 0 & 0 & 1 \\
EBO7 & 1,5 & 0 & 3 \\
G7 & 1 & 0 & 3 \\
FO14 & 0 & 0 & 0 \\
EBO14 & 2 & 1 & 2 \\
G14 & 1 & 1 & 2 \\
FO21 & 0 & 0 & 1 \\
EBO21 & 2 & 2 & 3 \\
G21 & 1 & 0 & 1 \\
\hline
\end{tabular}

Kruskal-Wallis test; $\mathrm{p}<0.0001$

TABLE 3 - Median, minimum and maximum values of parenchymal inflammation score in the groups Control (C), Fictitious Operation (FO), Extrahepatic Biliary Obstruction (EBO) and Treated with Glutamin (G) for 7, 14 and 21 days

\begin{tabular}{lccc}
\hline \multicolumn{1}{c}{ Groups } & Median & Min & Max \\
\hline C & 0 & 0 & 0 \\
FO7 & 0 & 0 & 0 \\
EBO7 & 1 & 0 & 2 \\
G7 & 2 & 1 & 2 \\
FO14 & 1 & 0 & 1 \\
EBO14 & 2 & 1 & 2 \\
G14 & 1,5 & 1 & 3 \\
FO21 & 1 & 0 & 1 \\
EBO21 & 2,5 & 1 & 3 \\
G21 & 1 & 0 & 1 \\
\hline K
\end{tabular}

Kruskal-Wallis test; $\mathrm{p}<0.0001$

TABLE 4 - Median, minimum and maximum values of hepatocytic changes score in the groups Control (C), Fictitious Operation (FO), Extrahepatic Biliary Obstruction (EBO) and Treated with Glutamin (G) for 7, 14 and 21 days

\begin{tabular}{lccc}
\hline \multicolumn{1}{r}{ Groups } & Median & Min & Max \\
\hline C & 0 & 0 & 0 \\
FO7 & 0 & 0 & 0 \\
EBO7 & 2 & 1 & 4 \\
G7 & 2 & 2 & 3 \\
FO14 & 0 & 0 & 1 \\
EBO14 & 2,5 & 2 & 3 \\
G14 & 3 & 2 & 4 \\
FO21 & 1 & 1 & 1 \\
EBO21 & 3 & 3 & 3 \\
G21 & 3 & 3 & 3 \\
\hline
\end{tabular}

Kruskal-Wallis test; $\mathrm{p}<0.0001$ 
TABLE 5- Median, minimum and maximum values of thrombi, biliary lakes and cholestasis scores in the groups Control (C), Fictitious Operation (FO), Extrahepatic Biliary Obstruction (EBO) and Treated with Glutamin (G) for 7, 14 and 21 days

\begin{tabular}{lccc}
\hline \multicolumn{1}{r}{ Groups } & Median & Min & Max \\
\hline C & 0 & 0 & 0 \\
FO7 & 0 & 0 & 0 \\
EBO7 & 0 & 0 & 1 \\
G7 & 0 & 0 & 2 \\
FO14 & 0 & 0 & 0 \\
EBO14 & 0 & 0 & 1 \\
G14 & 0 & 0 & 0 \\
FO21 & 0 & 0 & 0 \\
EBO21 & 0 & 0 & 0 \\
G21 & 0 & 0 & 0 \\
\hline
\end{tabular}

Kruskal-Wallis test; $\mathrm{p}<0.0001$

TABLE 6 - Median, minimum and maximum values of duct proliferation score in the groups Control (C), Fictitious Operation (FO), Extrahepatic Biliary Obstruction (EBO) and Treated with Glutamin $(\mathrm{G})$ for 7, 14 and 21 days

\begin{tabular}{lccc}
\hline \multicolumn{1}{r}{ Groups } & Median & Min & Max \\
\hline C & 0 & 0 & 0 \\
FO7 & 0 & 0 & 0 \\
EBO7 & 1,5 & 0 & 2 \\
G7 & 2 & 1 & 3 \\
FO14 & 0 & 0 & 0 \\
EBO14 & 2,5 & 2 & 3 \\
G14 & 3 & 3 & 4 \\
FO21 & 0 & 0 & 0 \\
EBO21 & 4 & 2 & 4 \\
G21 & 3 & 2 & 4 \\
\hline
\end{tabular}

Kruskal-Wallis test; $\mathrm{p}<0.0001$

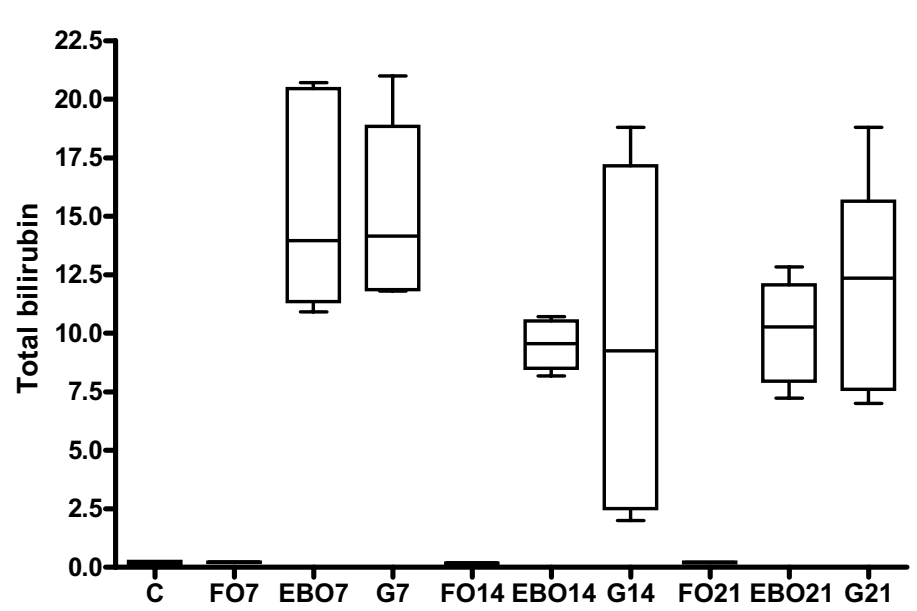

FIGURE 1 - Total bilirubin serum levels in the groups Control (C), Fictitious Operation (FO), Extrahepatic Biliary Obstruction (EBO) and Treated with Glutamin (G) for 7, 14 and 21 days

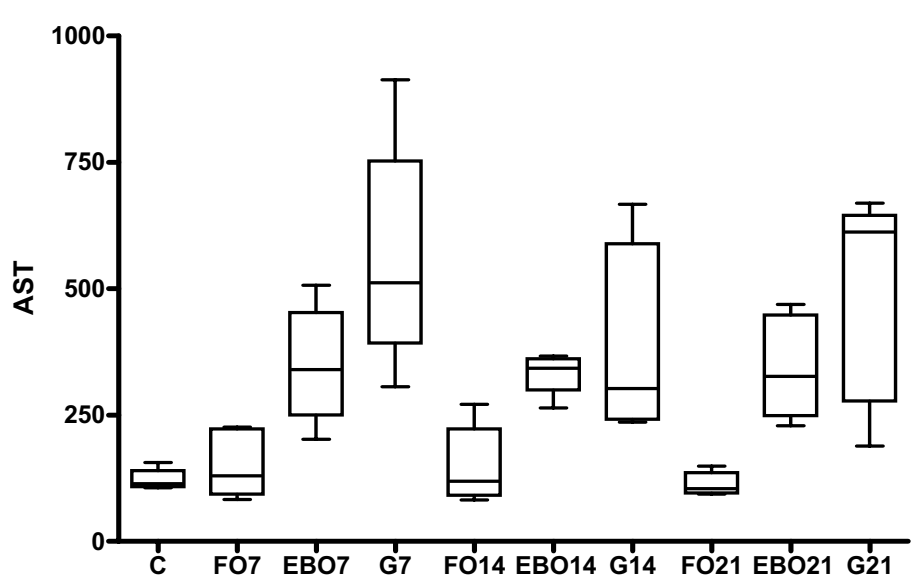

FIGURE 2 - Aspartate aminotransferase (AST) serum levels in the groups Control (C), Fictitious Operation (FO), Extrahepatic Biliary Obstruction (EBO) and Treated with Glutamin $(\mathrm{G})$ for 7 , 14 and 21 days

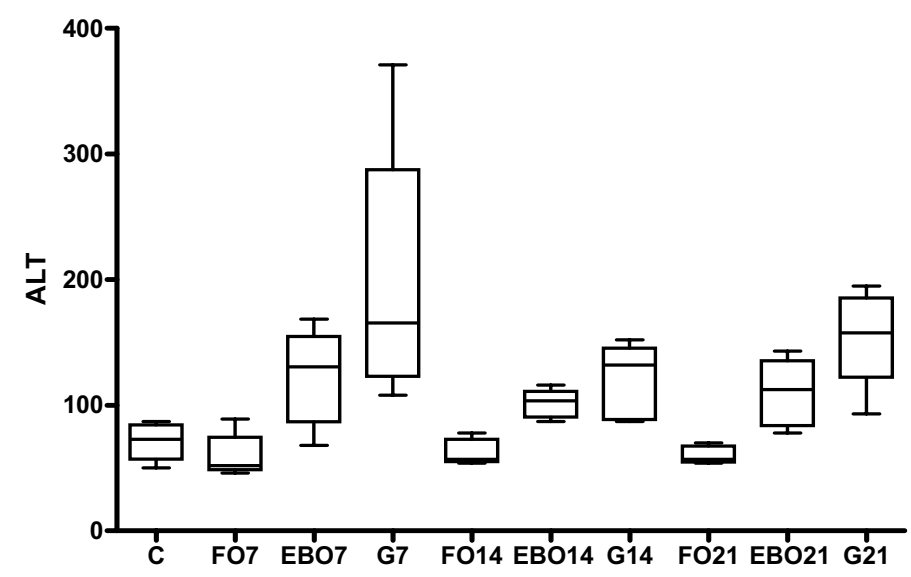

FIGURE 3 - Alanine aminotransferase (ALT) serum levels in the groups Control (C), Fictitious Operation (FO), Extrahepatic Biliary Obstruction (EBO) and Treated with Glutamin $(\mathrm{G})$ for 7 , 14 and 21 days

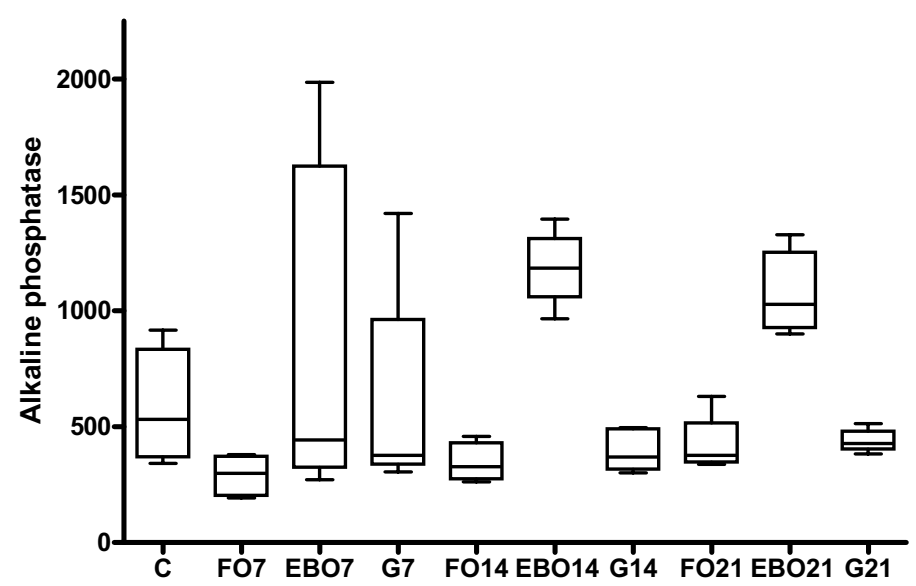

FIGURE 4 - Alkaline phosphatase (FAL) serum levels in the groups Control (C), Fictitious Operation (FO), Extrahepatic Biliary Obstruction (EBO) and Treated with Glutamin (G) for 7 , 14 and 21 days 


\section{Discussion}

Obstructive jaundice is a frequent manifestation of malignant or benign diseases of extrahepatic biliary ducts with high morbidity and postoperative mortality rates ${ }^{1,19}$. Patients with jaundice usually undergo various invasive diagnostic and therapeutic procedures, which is associated with these high rates of complications and deaths. The main reported complications are sepsis, hemorrhage, kidney disorders, hypersensitivity to endotoxin, among others ${ }^{19,20}$.

Several experimental and clinical studies have examined the impact of glutamine supplementation in several disease states. In humans, glutamine has been enterally administered in doses ranging from 20 to $30 \mathrm{~g}$ / day and parenterally from 12 to $40 \mathrm{~g}$ / day, in conditions such as post-cholecystectomy, post trauma, septic complications and after bone marrow transplantation. All these studies showed an improvement in nitrogen balance and muscle protein balance, also showing that the risk of patients developing infectious complications after surgery or trauma could be reduced. However, all these studies failed to demonstrate reduction in mortality rate and length of hospital stay ${ }^{15}$.

Our study, using hepatic duct ligation as a model of extrahepatic cholestasis, allowed all the changes due to cholestasis both in groups with and without treatment with glutamine as in its subgroups of 7, 14 and 21 days.

Many authors have postulated that glutamine can prevent or reduce the total bilirubin values. However, several experimental studies have documented conflicting results, which were attributed to the animal models used ${ }^{13}$. In our study, as for the serum levels of BT, TGO, TGP and FAL; an increase in these values was observed for groups submitted to extrahepatic biliary obstruction with and without treatment with glutamine compared to control and fictitious operation groups; however, no statistical difference between group submitted to obstruction treated with glutamine and the group only submitted to obstruction was observed. Another study, testing the enteral glutamine supplementation $(1 \mathrm{mg} / \mathrm{kg} / \mathrm{d})$ in rats submitted to 7 days of extrahepatic biliary obstruction with double ligation followed by resection between ligations, showed serum BT and Gamma GT levels significantly lower and serum TGP levels significantly higher in the group receiving glutamine supplementation ${ }^{14}$.

In our study, the histopathological analysis of fibrosis, portal inflammation, parenchymal inflammation, hepatocytic changes and duct proliferation showed signs of hepatitis and factors related to biliary obstruction in all individuals from groups submitted to extrahepatic biliary obstruction, with and without treatment with glutamine compared to control and fictitious operation groups; however, no statistical difference between group submitted to obstruction treated with glutamine and group submitted to obstruction only was observed. Regarding the presence of thrombi, biliary lakes and cholestasis, no statistical difference between groups was observed. A study with groups of 5 animals involving double ligation followed by resection between points showed that the administration of glutamine, by means of gavage $(0.2 \mathrm{~g} / \mathrm{kg}$ of body weight once daily), decreased the hepatocyte apoptosis and bile duct proliferation in rats after 3 days of ligation, not showing the same effect 7 days after operation ${ }^{15}$. Another study, with double ligation followed by resection, with groups of 15 animals showed that glutamine 3\% administration ad libitum resulted in decreased duct proliferation in the group without glutamine supplementation ${ }^{15}$.

\section{Conclusion}

Through the results obtained in this study, glutamine orally administered did not improve the parameters related to liver enzymes and histological changes due to biliary obstruction after 7, 14 and 21 days of treatment.

\section{References}

1. O'Connor MJ. Mechanical biliary obstruction. A review of the multisystemic consequences of obstructive jaundice and their impact on perioperative morbidity and mortality. Am Surg. 1985; 51(5):245-51.

2. Scott-Conner CE, Grogan JB. The pathophysiology of biliary obstruction and its effect on phagocytic and immune function. J Surg Res. 1994; 57(2):316-36.

3. Yang R, Martin-Hawver L, Woodall C, Thomas A, Qureshi N, Morrison D, Van Way C 3rd. Administration of glutamine after hemorrhagic shock restores cellular energy, reduces cell apoptosis and damage, and increases survival. JPEN Parenter Enteral Nutr. 2007;31(2):94-100.

4. Jing L, Wu Q, Wang F. Glutamine induces heat-shock protein and protects against Escherichia coli lipopolysaccharide-induced vascular hyporeactivity in rats. Crit Care. 2007;11:R34.

5. Sheen-Chen SM, Hung KS, Ho HT, Chen WJ, Eng HL. Effect of glutamine and bile acid on hepatocyte apoptosis after bile duct ligation in the rat. World J. Surg. 2004;28:457-60.

6 . Yang RR. The effect of glutamine on cholestasis caused by total parenteral nutrition. Zhonghua Wai Ke Za Zhi. 1993;31(2):94-6.

7. Castro e Silva O, Franco CFF, Souza MEJ, Picinato MAN, Zucoloto S, Ceneviva R. Alterações hepáticas e níveis séricos de aminotransferases 24 horas após ligadura do ducto hepático em ratos. Acta Cir Bras. 1991;6(4):159-61.

8. Koyama K, Ito K, Ouchi K, Sato T. Mitochondrial function of rat liver in biliary obstruction. Tohoku J Exp Med. 1980;131(1):59-69.

9. Häussinger D, Schliess F. Glutamine metabolism and signaling in the liver. Front Biosci. 2007;12:371-91.

10. Urbina JJO, Jorquera F, Culebras J, Villares C, González-Gallego J, Tuñón MJ. Influencia de la formulación de la glutamina en sus efectos sobre los sistemas antioxidantes y de destoxificación hepática en la rata. Nutr Hosp. 2004;2:73-82.

11. Muriel P, González P. Liver damage induced by acute cholestasis in the rat is ameliorated partially by L-arginine. Comp Biochem Physiol C Pharmacol Toxicol Endocrinol. 1998;120(3):421-4.

12. Newsholme P. Why is l-glutamine metabolism important to cells of the immune system in health, postinjury, surgery or infection? J Nutr. 2001;131(9 Suppl):2515S-22S.

13. Salvalaggio PR, Neto CZ, Tolazzi AR, Gasparetto EL, Coelho JC, Campos AC. Oral glutamine does not prevent bacterial translocation in rats subjected to intestinal obstruction and Escherichia coli challenge but reduces systemic bacteria spread. Nutrition. 2002;18(4):334-7.

14. Celebi F, Gurkan O, Kizilkaya M. The effects of combined use of glutamine and growth hormone on the bacterial translocation associated with ostrucive jaundice. Saudi Med J. 2008;29(7):989-93.

15. Margaritis VG, Filos KS, Michalaki MA, Scopa CD, Spiliopoulou I, Nikolopoulou VN, Vagianos CE. Effect of oral glutamine administration on Bacterial Translocation, Endotoxemia, Liver and Ileal Morphology, and apoptosis in rats with obstructive jaundice. World J Surg. 2005;29:1329-34. 
16. Luo M, Bazargan N, Griffith DP, Estívariz CF, Leader LM, Easley KA, Daignault NM, Hao L, Meddings JB, Galloway JR, Blumberg JB, Jones DP, Ziegler TR. Metabolic effects of enteral versus parenteral alanyl-glutamine dipeptide administration in critically ill patients receiving enteral feeding: a pilot study. Clin Nutr. 2008;27(2):297-306. 17. Melis GC, Boelens PG, van der Sijp JR, Popovici T, De Bandt JP, Cynober $\mathrm{L}$, et al. The feeding route (enteral or parenteral) affects the plasma response of the dipetide Ala-Gln and the amino acids glutamine, citrulline and arginine, with the administration of Ala-Gln in preoperative patients. Br J Nutr. 2005;94:19-26.
18. Boelens PG, Melis GC, van Leeuwen PA, ten Have GA, Deutz NE. Route of administration (enteral or parenteral) affects the contribution of L-glutamine to de novo L-arginine synthesis in mice: a stable-isotope study. Am J Physiol Endocrinol Metab. 2006;291(4): E683-90.

19. Minter RM, Fan MH, Sun J, Niederbichler A, Ipaktchi K, Arbabi S, Hemmila MR, Remick DG, Wang SC, Su GL. Altered Kupffer cell function in biliary obstruction. Surgery. 2005;138:236-45.

20. Clements WDB, Diamond T, McCrory DC, Rowlands BJ. Biliary drainage in obstructive jaundice: experimental and clinical aspects. Br J Surg. 1993;80:534-8.

\section{Correspondence:}

João Batista de Sousa

Campus Universitário Darcy Ribeiro

Prédio da Reitoria, $2^{\circ}$ pavimento, sala B2-16

70910-900 Brasília - DF Brazil

Phone: (55 61)3307-2201

sousajb@unb.br

Conflict of interest: none

Financial source: none

\section{How to cite this article}

Paiva Neto MC, Almeida REF, Xavier MM, Takano GHS, Castro e Silva O, Cruz CAT, Sousa JB. Influence of glutamine on morphological and functional changes of liver in the presence of extrahepatic biliary obstruction in rats. Acta Cir Bras. [serial on the Internet] 2010 July-Aug;25(4). Available from URL: http://www.scielo.br/acb 